\title{
Website for scientific dissemination of research on problem-based learning with highschool chemistry teachers: Contexts of an investigation
}

\author{
Website para divulgação científica de pesquisas sobre aprendizagem baseada em com professores \\ de química do ensino médio: Contextos de uma investigação \\ Sitio web de divulgación científica de investigaciones sobre aprendizaje basado en problemas com \\ professores de química de secundaria: Contextos de una investigación
}

Received: 05/04/2021 | Reviewed: 05/11/2021 | Accept: 05/18/2021 | Published: 06/04/2021

\author{
Amanda Pereira de Freitas \\ ORCID: https://orcid.org/0000-0001-5994-416X \\ Universidade Federal Rural de Pernambuco, Brazil \\ E-mail: amandafreitaspd@gmail.com \\ Angela Fernandes Campos \\ ORCID: https://orcid.org/0000-0002-1294-3124 \\ Universidade Federal Rural de Pernambuco, Brazil \\ E-mail: afernandescampos@gmail.com
}

\begin{abstract}
The aim of this study was to carry out the scientific dissemination of research on problem-based learning (PBL) with highschool Chemistry teachers through a website and to investigate their opinions on this digital resource. Also, analyse the knowledge of teachers about PBL and its use in the classroom. The set of data was collected through of a semi-structured interview conducted with ten highschool Chemistry teachers in the city of Recife - Pernambuco, Brazil. Analysis of data implied that teachers know PBL and that they use it in the classroom, however with some difficulties. In general, their opinions about the website were positive and significant. Most of them commented that the website will serve as a didactic support in the preparation of their lessons providing access to solutions to various problematic situations regarding different contents in chemistry. Furthermore, the website will allow basic education teachers to have access to knowledge that has been discussed in Brazilian universities.
\end{abstract}

Keywords: Scientific dissemination; Problem-based learning; Chemistry teachers; Teaching.

\section{Resumo}

O objetivo deste estudo foi realizar a divulgação científica de pesquisas sobre aprendizagem baseada em problemas (PBL) com professores de Química do ensino médio por meio de um website e investigar suas opiniões sobre este recurso digital. Além disso, analisar o conhecimento dos professores sobre PBL e seu uso em sala de aula. O conjunto de dados foi coletado por meio de entrevista semiestruturada realizada com dez professores de Química do ensino médio da cidade de Recife - Pernambuco, Brasil. A análise dos dados mostrou que os professores conhecem o PBL e o utilizam em sala de aula, porém com algumas dificuldades. Em geral, suas opiniões sobre o website foram positivas e significativas. A maioria deles comentou que o website servirá como um suporte didático na preparação das suas aulas proporcionando o acesso a soluções para várias situações problemáticas em relação aos diferentes conteúdos da química. Além disso, o website permitirá que professores da educação básica tenham acesso a conhecimentos que vêm sendo discutidos nas universidades brasileiras.

Palavras-chave: Divulgação científica; Aprendizagem baseada em problemas; Professores de química; Ensino.

\section{Resumen}

El objetivo de este estudio fue realizar la divulgación científica de la investigación sobre el aprendizaje basado en problemas (ABP) con profesores de química de secundaria a través de un sitio web e investigar sus opiniones sobre este recurso digital. Además, analizar el conocimiento de los profesores sobre ABP y su uso en el aula. El conjunto de datos se recopiló a través de una entrevista semiestructurada realizada con diez profesores de química de secundaria en la ciudad de Recife - Pernambuco, Brasil. El análisis de datos mostró que los profesores conocen el ABP y lo utilizan en el aula, pero con algunas dificultades. En general, sus opiniones en el sitio web fueron positivas y significativas. La mayoría de ellos comentaron que el sitio web les servirá de soporte didáctico en la preparación de sus clases, dando acceso a soluciones para diversas situaciones problemáticas en relación a los diferentes contenidos de la química. Además, el sitio web permitirá que los docentes de educación básica tengan acceso a conocimientos que se han discutido en las universidades brasileñas.

Palabras clave: Divulgación científica; Aprendizaje basado en problemas; Profesores de química; Enseñanza. 


\section{Introduction}

Problem-based learning (PBL) can actually be considered a research trend that has been developed in the field of Science Didactic and in the area of Chemistry teaching in Brazil (Freitas \& Campos, 2019). It consists in an approach based mainly on a constructivist perspective to promote the improvement of teaching and enable student with active and meaningful learning. It has a conception of teaching and learning, as its core, in which the teacher assumes the role of advisor / mediator to be built in the school environment. And the student, in turn, is considered an autonomous individual and primarily responsible for building his own knowledge. Günter and Alpat (2017) consider that Problem-based learning (PBL) is a active learning method used in the teaching process in order to produce individuals who are creative, can adapt themselves to team work and who are able to find solutions to the problems of daily life by using the knowledge and skills gained.

According to Overton and Randles (2015), Problem-based learning (PBL) first appeared in 1969 as a new approach to medical education at McMaster University in Canada. It was developed as an educational approach drawing on research on Philosophy, Psychology and research on Education. Neurologist Howard S. Barrows (1986) is considered the pioneer in presenting students with patient problems to solve in small groups and requiring them to seek relevant knowledge in an effort to solve those problems (Tawfik, 2015). According to Tawfik (2015) theoretical work of Barrows has generated widespread influence and research questions within and across disciplines.

Actually, in Chemistry there are many studies in this direction. For example, there is PBL approaches on society themes such as environment, energy, public health (Nagarajan \& Overton, 2019); Academic achievement of students studying 'Electrochemistry' (Gunter: Alpat 2017); Understanding 'green chemistry' and 'sustainability' (Günter, Akkuzu \& Alpat, 2017); Thermodynamic Teaching (Baran \& Sozbilir, 2018); Interdisciplinary Explorations in an Advanced Biochemistry Class (Cowden, Santiago \& 2016). Also, PBL has been widely used as a potential for teaching the phenomenological aspect of chemical knowledge in various branches of Chemistry, inorganic (Shultz; Zemke, 2019), organic (Costantino \& Barlocco, 2019) and physical (Hicks \& Bevsek, 2012).

In Brazil, there are many investigations under this perspective published in several scientific journals about chemistry teaching and learning (Merino \& Herrero, 2007; Lopes et al.., 2011; Verissimo \& Campos, 2011; Lacerda et al., 2012; Fernandes \& Campos, 2014; Ferreira, et al. 2016, Goi \& Santos, 2020; Silva \& Braibante, 2020) that present PBL as potential development learning related to conceptual, procedural and attitudinal content in Chemistry. Some of these investigations were developed by professors and researchers from RPEQ (acronym that stands for Resolução de Problemas no Ensino de Química and means Problem Solving in Chemistry Teaching) research group at the Federal Rural University of Pernambuco (UFRPE), as a result of projects developed by students of the Master of Science in Teaching - UFRPE, Specialization in teaching Chemistry and Scientific Initiation. However, these results, as well as their contributions to improving the teaching and learning process, have not been appropriated by highschool Chemistry teachers. This, in part, is due to the lack of scientific dissemination in Brazilian schools (Torresi et al., 2012).

According to Melo (1982) apud Nascimento (2008), scientific dissemination activities must promote the popularization of knowledge that is being produced in our universities and research centers. Under this conception, we understand scientific dissemination as an act or feat of making scientific knowledge accessible through the dissemination of the productions developed both by academic institutions and by research centers.

In this sense, the National Curriculum Guidelines for Initial and Continuing Teacher Education (Brasil, 2015) recommend that higher education professors who are also researchers must disseminate scientific and technological knowledge in specific fields as Chemistry, Biology, Physics, etc., as well as in the field of Education (teaching strategies, teaching resources, etc.) besides doing their research. 
In Brazil, according to Barata (2018), the last few decades have brought together scientists, journalists, publishers and government representatives to invest and legitimize science communication in Brazil. The authors also comment that Brazilian universities and research institutions have expanded their science communication interest in recent years, either in communication or other faculties such as linguistics, education and health.

Internationally, according to Nascimento and Rezende Júnior (2010), periodics such as "Public Understanding of Science", "International Journal of Science and Education" and "Science Education" have contributed to the establishment of the relations between the science communication and the various ways of promoting the popularization of science. The authors comment that different international studies (Millar (1996), Fensham (1999), Laughsch (2000), Bak (2001), Turney (2004), Turner (2008)) bring research focused on scientific dissemination articulated to science teaching. Still, in this direction, Masih presents a study entitled "Efforts Towards Popularization and Public Understanding of Science: A Literature Review of 30 publications" discussing on wide spectrum of popularization methods for bringing Scientists, Industry, Government Organizations, R\&D laboratories together for creating a scientific temper by encouraging science communication and popularizing.

In order to promote scientific dissemination, one can use resources, techniques, products (vehicles or channels) and processes that enable the transmission of information to the general public (Bueno, 2010). Among these resources are Information and Communication Technologies - ICT. For this study, we made use of digital technologies, in particular, the use of the internet through websites (Kenski, 2015). According to Groth and Gurney (2010) scientific discourse on the web is more immediate, contextually relevant and has a larger non-technical focus than the academic literature.

Based on what has been presented so far, the purpose of this study was to build a website aiming to systematize the research studies developed about PBL (Problem-based learning) published in several scientific periodics by the RPEQ group. And, this way, start the scientific dissemination of these studies, in order to draw basic education chemistry teachers closer to this teaching approach and to the research developed in the university academic environment. Also, this study aims to analyze whether highschool chemistry teachers are aware of and what their opinion about a PBL website aimed at teaching Chemistry is.

\section{A few Considerations on the Concepts of Scientific Dissemination, Communication and Diffusion}

Although the terms dissemination, communication and diffusion seem to have the same meaning, their concepts differ in some aspects, especially in relation to their target audience. For Pasquali (1979), scientific diffusion consists of sending messages elaborated in codes or languages that are comprehensible to the entire population. On the other hand, Bueno (2008) understands that this concept limits scientific diffusion to a non-specialized universal audience, excluding the use of the concept of diffusion for an audience of experts in the area of science and technology. Thus, Bueno (2008) re-elaborates the concept of Pasquali and conceptualizes scientific diffusion as any and all processes used to communicate scientific and technological information to a lay audience and to an audience of experts. When reflecting scientific diffusion in such a way, Bueno (2008) presents two aspects for scientific diffusion: 1) diffusion directed to specialists called scientific communication and 2) diffusion directed to the general public, which the author calls scientific dissemination. For a better visualization of what was stated by Bueno (2008), Castelo Branco (2015) presents the following graphical representation (Figure 1). 
Figure 1 - Representation of Bueno's concepts for the terms scientific diffusion, communication and dissemination.

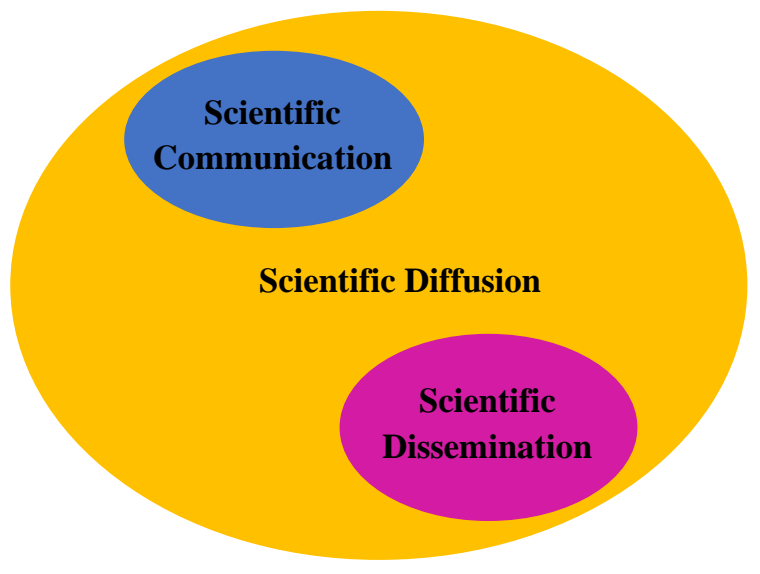

Source: Castelo Branco (2015).

Bueno (2010) draws attention to the audience for which scientific communication is intended. For him, scientific communication comprises two levels called intrapares and extrapares. Intrapare communication comprises the circulation of information addressed to groups of experts within a field or related areas. Whereas extrapare communication refers to the circulation of this information directed at groups of experts that are not exclusively inserted in the area of the object of the dissemination through academic qualification or professional performance.

For Bueno (2010), the concept of scientific dissemination includes the use of resources, techniques and processes for the circulation of scientific and technological information to the general public. Regarding scientific dissemination activities, Melo (1982) apud Nascimento (2008) advocates that they should be mainly educational. The author points out the educational function of scientific dissemination as a source of fundamental knowledge for overcoming situational problems present in the daily lives of citizens. Melo (1982) also emphasizes that scientific dissemination must disseminate knowledge which is being produced both in universities and in research centers, in order to democratize knowledge serving all kinds of different audiences.

Therefore, we understand that academic production directed at the teaching of science is also included in the information that must be conveyed to a non-specialist audience. In our case, the public of non-specialists refers to individuals who are not researchers in the field of Science Education. Thus, we believe that the dissemination of this nature of research, especially of studies carried out in the area of teaching Chemistry to non-specialized public (those who are not researchers in the field of Science Didactics), becomes relevant in the sense of providing knowledge of the problem solving approach to teachers. And, in addition to this, encourages the use of these researches in the context of schools, since they have a positive result in promoting learning of chemical concepts.

\section{ICT in Promoting Scientific Communication and Dissemination}

The concept of Information and Communication Technology (ICT) is used to express the link between information technology and telecommunications. In this sense, ICTs accommodate computer and telecommunication tools such as radio, television, internet, video, etc. All of this technological support has as one of its objectives the use of the means of telecommunications to facilitate the dissemination of information (Groth \& Gurney, 2010; Leite, 2015).

Among ICT resources are digital technologies. According to Kenski (2015), digital technology is a category of ICT, in which computing (informatics and its applications), communications (transmission and reception of data through networks) and different types of support on which contents are available (texts, books, films, magazines) gather. So, for this study, we 
made use of these digital technologies, especially the internet through a website, to carry out the dissemination and scientific communication of research on problem solving in Chemistry.

With the advance of internet, associated with its emergence and popularization, it became necessary to use efficient search tools, which were able to assist both teachers and students in the teaching and learning process (Santos et al.., 2008) such as, digital repositories and digital teaching resources aimed at the educational area.

According to Nascimento (2009, p.352), "Digital repositories serve to store content that can be browsed through search and accessed for reuse". In the words of Leite (2015, p.223), digital repositories, in addition to storing content, are also used to "preserve, organize and disseminate the results of intellectual production by scientific communities, being characterized for their transparent public access".

In order to broaden this concept to an educational context, digital repositories can be understood as virtual deposits or as a database in which it is possible to find and access educational resources that address various contents in different levels of education (Leite, 2015).

The research done by Castro et al. (2015) indicates internet pages and repositories for educational purposes as potential contributions in order that the content available on these virtual sites can be integrated into pedagogical practice of teachers.

Concerning digital didactic resources, Leite (2015) explains that they stand for all material used to assist the teaching and learning process of scientific content and can be used by teachers with their students, as well as by students without the help of their teachers. From this conception, the referred author conceptualizes digital didactic resources as being all the learning objects elaborated with the use of digital technologies, which help individuals in the learning process.

Based on the conjectures above, we understand that digital information and communication technologies can assist teachers in the teaching and learning process, provide they have access to reliable sources of information which supply them with knowledge of different didactic-pedagogical approaches in addition to scientific knowledge.

\section{Methodology}

The present research is of a qualitative nature, considering that this type of approach allows us to analyze the speech and writing of participants in a descriptive and interpretative way, through reflection and data exploration (Oliveira, 2016).

This study was carried out with ten chemistry teachers from public schools in the city of Recife, in the state of Pernambuco called here by the codes T01 to T10. The ten participants in this research have an under graduation degree and most of them have a major in Chemistry. One owns a bachelor's degree, five have a degree with a major in Chemistry and one has a degree in Science with a major in Chemistry. The other teachers belong to the area of Biology and Biochemistry. Table 1 shows the list of teachers and their respective areas of training. 
Table 1 - Field of Academic Qualification of the participants.

\begin{tabular}{|c|c|c|}
\hline \multirow{2}{*}{ Field of Academic Qualification } & Undergraduation Degree & Teachers \\
\hline \multirow{2}{*}{ Chemistry } & Licentiate degree & T01, T02, T04, T07, T10 \\
\cline { 2 - 3 } & Bachelor's degree & T06 \\
\hline Biology & Licentiate degree & T05, T09 \\
\cline { 2 - 3 } & Bachelor's degree & T09 \\
\hline Science with a major in Chemistry & Licentiate degree & T08 \\
\hline Biochemistry & Bachelor's degree & T03 \\
\hline
\end{tabular}

Source: Authors.

With regard to graduate courses, the participants have specialization and master's degrees in different areas of knowledge. Only two teachers, T01 and T09, do not have a graduate degree. In table 2, we list the participants' graduate level and their corresponding knowledge area. It should be noted that all graduation courses referred to by the participants have been completed.

Table 2 - Graduate degree of the participants and corresponding knowledge area.

\begin{tabular}{|c|c|c|}
\hline Teacher & Graduation Degree & Field of Study \\
\hline T02 & Master's Degree & Organic Chemistry \\
\hline T03 & Specialization & Vocational Education Courses \\
\hline T04 & Master's Degree & Science Teaching \\
\hline T05 & Specialization & Food Science and Technology \\
\hline T06 & Master's Degree & Education Sciences \\
\hline T07 & Master's Degree & Chemistry Teaching \\
\hline & Specialization & Biochemistry \\
\hline T08 & Master's Degree & Chemistry Teaching, School Management and Environmental \\
& Specialization & Management \\
\hline
\end{tabular}

Source: Authors.

To achieve the objectives of this study, the methodological path was organized in three phases. In the first phase, a website on problem solving in the teaching of Chemistry was built. In the second phase, teachers' knowledge of the problem 
solving approach and the use of this approach in the classroom was verified. And the third phase referred to the dissemination of the website to chemistry teachers in schools and the feedback about the opinions of these teachers regarding the website.

\section{Phase 1 - Construction of the RPEQ website}

The website on Problem Solving in Chemistry Teaching (RPEQ) constitutes the means of scientific dissemination of research on the approach that applies problem solving in the teaching and learning of Chemistry. Its objective is to systematize studies about this approach developed nationally, contributing to the dissemination of knowledge produced by the academic community. The dissemination of scientific productions on problem solving in Chemistry available on the website has two distinct natures:

(i) Scientific Dissemination - in this sense, we seek to carry out actions in schools, such as the dissemination of research on teaching and learning approaches based on problem solving to teachers through the RPEQ website (phases 2 and 3). This way we seek to bring basic education teachers of schools in the city of Recife closer to the research published on the website and developed by the field of Didactics of Sciences, especially the research on the problem solving approach. Thus, the idea is to enable teachers to understand these studies and apply them in the school context in the future.

(ii) Scientific Communication - From this perspective, the RPEQ website aims to communicate current thoughts on problem solving in Chemistry to a specific audience in the field of Chemistry and that is interested in starting from existing texts, deepen discussions and to contribute to the unfolding of new lines of research.

As presented so far, the website built in one of the phases of this research has the following purposes (Figure 2).

Figure 2 - Purposes of the website on problem solving in Chemistry.

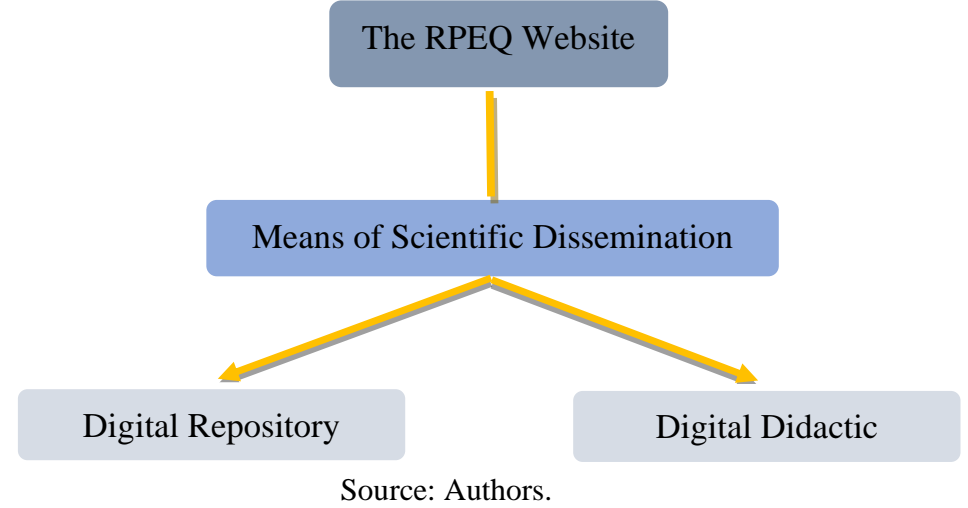

The website is also configured as a digital repository besides being the means of scientific dissemination and communication of research on problem solving in Chemistry. The studies developed about this theme are systematically stored, allowing other people to use these researches. On the other hand, the RPEQ website is also characterized as a digital didactic resource for teachers, since it corresponds to a collection of didactic materials on problem solving for the teaching of Chemistry, functioning as a tool that can assist the teacher in the preparation of activities based on this approach.

\section{Construction and Structure of the RPEQ website}

The construction of the website was carried out by a specialized company, however we actively participated in the entire elaboration process. The RPEQ website is available on the internet at the electronic address www.rpeq.ufrpe.br and displays 
the following layout and structure (Figure 3). The RPEQ website displays six tabs: Home, RPEQ, Theoretical Framework, Publications, RPEQ Situational Problems and Events (Figure 3).

Figure 3 - Layout and structure of the RPEQ website.

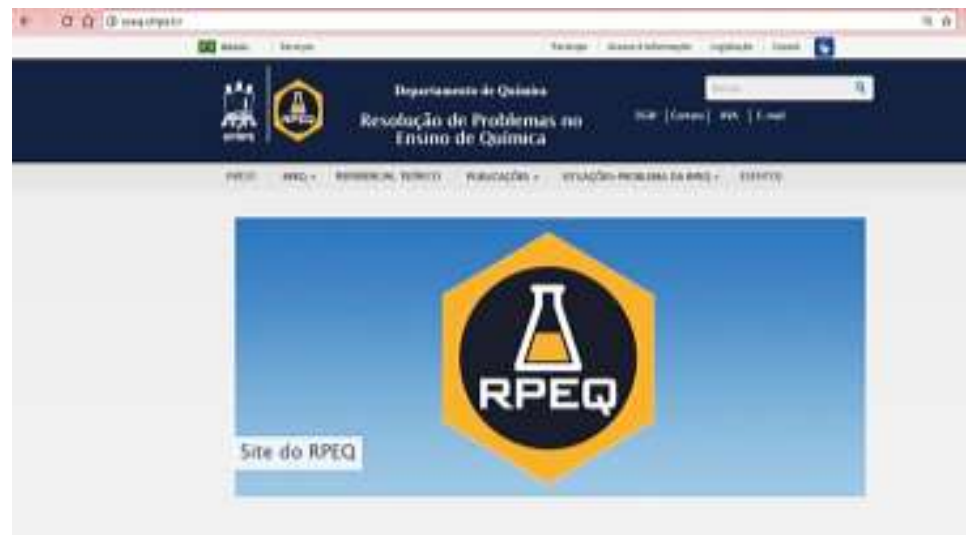

Source: www.rpeq.ufrpe.br.

In the Home, news related to Chemical Science and Chemistry teachings are presented. The RPEQ tab provides information about the research group, its members and their contact email addresses.

In Publications there are listed the research studies that were developed by the RPEQ group at the Federal Rural University of Pernambuco - UFRPE and published in different scientific journals. The situational problems that were developed in these studies, as well as the didactic resources and activities that were developed to assist in their resolution are systematized in the RPEQ Situational Problems tab.

The RPEQ Situational Problems tab lists research on problem solving in Chemistry developed by the group grounded in PBL. The studies are organized according to the areas of knowledge in Chemistry such as inorganic chemistry, analytical chemistry, physical chemistry and organic chemistry. In these subtabs of the Situational Problems tab there are the lesson plans in the PDF (Portable Document Format) file (Figure 4), which were extracted from the research published in the scientific journals listed in the Publications tab. These lesson plans describe the situational problems, the didactic resources and activities used to assist the student in the process of solving the situational problems. Under the link for each lesson plan is the article from which the activity was taken (Indicated in blue in Figure 4) in case the user wants to access the content of these lesson plans in its entirety. 
Figure 4 - List of situational problems on general and inorganic chemistry found on the RPEQ website.

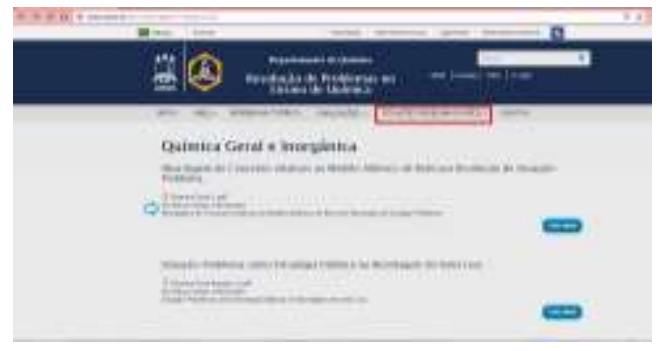

Source: www.rpeq.ufrpe.br.

In regard to the remaining tabs, the Theoretical Framework presents a brief discussion about the theory that underlies the research on the issue of problem solving. In the Events tab, there will be announced conferences, meetings and gatherings in the field of Chemistry and Science teaching.

\section{Phase 2 - Verification of teachers' knowledge of problem solving (PBL) and the use of this approach in the classroom}

In order to carry out our research, we went to seven public schools that belong to the state's mainstream network in Recife - Pernambuco to talk to the teachers in order to explain the purpose of the study. Then, we scheduled a day with a set time to make these teachers acquainted with the RPEQ website, introduce them to the researches on problem solving that are available on the website and conduct an interview. Such activities took place all together on the same day at schools where the teachers worked. Altogether, ten meetings were held with ten teachers with an average duration of one hour and thirty minutes.

Before presenting to teachers the studies on problem solving systematized on the RPEQ website, we conducted a semi-structured interview mediated by a questionnaire of diagnosis containing open-ended and closed-ended questions, with the aim of conducting a study on the relationship of the subjects with the problem-solving approach. In this case, the purpose was to verify whether the teachers were familiar with the problem solving teaching and learning approach and whether they knew or used this didactic approach in the classroom (Table 3).

Table 3 - Diagnostic Questionnaire.

\begin{tabular}{|c|c|}
\hline & About the Research \\
\hline Question 1 & $\begin{array}{l}\text { Do you participate or have participated in any continuing education activity for teachers } \\
\text { about any methodology, approach or didactic approach to teach Chemistry? If yes, which } \\
\text { one/ones? }\end{array}$ \\
\hline Question 2 & $\begin{array}{l}\text { Do you know the problem solving or situational problem teaching and learning approach? ( } \\
\qquad \text { ) Yes ( ) No }\end{array}$ \\
\hline \multirow[b]{3}{*}{ Question 3} & $\begin{array}{l}\text { Have you applied the problem solving teaching and learning approach in Chemistry lessons? } \\
\qquad\left(\begin{array}{l}\text { ) Yes ( ) No }\end{array}\right.\end{array}$ \\
\hline & If yes... \\
\hline & $\begin{array}{c}\text { - You have applied it: ( ) Once ( ) More than once. } \\
\text {-For which contents in Chemistry did you apply the problem solving approach? } \\
\text { - Did you find any difficulties in applying this approach in the classroom? If so, which } \\
\text { one/ones? }\end{array}$ \\
\hline
\end{tabular}

Source: Authors. 


\section{Phase 3 - Disclosure of the RPEQ website and inquiry on teachers' opinions about this website}

After completing the previous step, we presented the studies on problem solving in the teaching of Chemistry developed by the RPEQ group and systematized on the website to the teachers. Due to the fact that we did not know if schools had access to internet and given to the possibility of a failure in the mobile internet connection during the demonstration, we chose to take a printed version of the RPEQ website layout and of part of its content and provide teachers with the email address of the website so that they could access it at their convenience.

Therefore, we selected two situational problems on the content of Chemical Bonding, both available on the website in the RPEQ Problem Situation menu. We chose this theme because it is a basic subject matter that is studied in the first two years of high school. The situational problems presented to the teachers and their respective authors are shown in figures 5 and 6.

Figure 5 - Problem Situation 1 presented to teachers.

\section{Problem Situation 1}

Title of the Article: Metallic Bonding Approach in a Problem Situation Teaching Perspective

Six men were caught red handed stealing copper wires from the Oi telephone company. The police reached out to the suspects through anonymous reports that a gang was stealing the material. Upon arriving at the scene, the police found a bucket truck with 13 copper wire tubes. Each tube was about six meters long. According to information given by the suspects to the police, each kilogram of copper wire would be sold for R $\$ 7.00$ (seven reals/Brazilian currency). After being arrested, the group was sent to the Police Station of Boa Vista. All were charged with theft and conspiracy. The above news coverage reports the theft of copper wires. Why is this metal used in the transmission of electrical energy? How to explain its behavior considering the macroscopic, theoretical and representational aspects of chemical knowledge?

Source: Ferreira, Fernandes and Campos (2016).

Figure 6 - Problem Situation 2 presented to teachers.

\section{Problem Situation 2}

Title of the Article: Elaboration and Application of a Didactic Intervention by using a Problem Situation in the Teaching of Chemical Bonding

Diamond is a highly hard substance. Therefore, it is used in rock drilling. In its composition it has only carbon atoms. Graphite is a low resistant substance. It is used in the manufacture of pencils and also consists only of carbon atoms. On the hardness scale the Diamond is the hardest rated 10 and grafite is one of the softest materials with a hardness rated 1. Graphite is an electrical conductor unlike Diamond which is considered an insulator. Graphite is used in electric ovens because it conducts electricity. Why is there such a sharp difference in hardness in these substances since both are made up only of carbon? Why does only grafite conduct an electrical current? What kind of chemical bond occurs in these substances?

Source: Fernandes and Campos (2014).

All teachers were invited to read the two situational problems. After the teachers had read the research papers, we asked them to answer the following question: "What is your opinion about a website on which problems about various contents in Chemistry will be made available along with their respective didactic tools?". This question was aimed to raise the opinions of teachers in relation to the proposal of a website on problem solving for the teaching of Chemistry.

We emphasize that an audio recording took place during the entire interview. Thus, we made teachers feel at ease to choose the way of registering the answers (written or audio recording) to the first questionnaire and the final question. 


\section{Results and Discussion}

In order to analyze data collected in phase two, we made a descriptive and interpretative analysis of the teachers' answers to the questions. And to analyze the data collected in phase three, we used the Content Analysis technique proposed by Bardin (2011).

\section{Analysis of the Subjects' Knowledge of Problem Solving and the Use of this Approach in the Classroom}

Next we will present the analysis of the results obtained in phase two in relation to the following questions:

- Do you participate or have participated in any continuing education activity for teachers about any methodology, approach or didactic approach to teach Chemistry? If yes, which one/ones?

- Do you know the problem solving or situational problem teaching and learning approach? ( )Yes ( ) No

- Have you applied the problem-solving teaching and learning approach in Chemistry lessons? Once or more than once? For which contents in Chemistry did you apply the problem-solving approach? Did you find any difficulties in applying this approach in the classroom? If so, which one/ones?

As a result, for the first question listed above, we noticed that none of the subjects had participated in a continuing education activity directed at the problem solving learning in the teaching of Chemistry. Among continuing education activities mentioned by them were Laboratory Practices, Information and Communication Technologies and Concept Maps.

In relation to the other two questions, initially six teachers stated that they knew the problem solving approach and five declared that they had not used this approach in the classroom. However, it is worth making some observations concerning subjects T05 and T09. In regard to the second question, T05 stated to have only heard of problem solving. Therefore, we consider that T05 does not have a concrete knowledge about this approach. While T09, in relation to the third question, declared to have used problem solving in the classroom. Nevertheless, along the interview, we noticed that T09 referred to the use of problems only as a way to contextualize the content, not using this approach linked to a thoughtful and planned didactic sequence. Considering this context, we obtained the following result for question two: half of the interviewed teachers (5) said they knew how to solve problems and four of them said they had used this approach in the classroom (Table 4).

Table 4 - Teachers who know and have applied problem solving in the classroom.

\begin{tabular}{|c|c|c|c|}
\hline Teacher & \multicolumn{2}{|c|}{ Knows the problem solving teaching approach } & \multirow{2}{*}{$\begin{array}{c}\text { Has applied this approach in the classroom } \\
\text { Yes }\end{array}$} \\
\hline T01 & Yes & Through workshops & \\
\hline T02 & Yes & Through continuing education and articles & No \\
\hline T03 & - & No & No \\
\hline T04 & Yes & Through master's tutorials & Yes \\
\hline T05 & - & No & No \\
\hline T06 & - & No & No \\
\hline T07 & - & No & No \\
\hline T08 & Yes & Through continuing education & Yes \\
\hline T09 & - & No & No \\
\hline $\mathrm{T} 10$ & Yes & Through graduation program & Yes \\
\hline
\end{tabular}

Source: Authors. 
As mentioned by the teachers, the continuing education refers to courses promoted by the State Education Secretary (SEE - acronym that stands for the Portuguese Secretaria Estadual de Educação) or by the Universities of Pernambuco in partnership with schools. Therefore, this continuing education is not directed specifically towards a teaching approach, but towards different teaching strategies.

To the teachers who answered that they had applied the problem solving approach in the classroom, a total of four teachers, we also asked how many times they had used it, what content had been covered and if they had had any difficulties. The answers to these questions are shown in Table 5.

Table 5. Teachers who reported having applied problem solving in the classroom.

\begin{tabular}{|c|c|c|c|c|}
\hline Teacher & $\begin{array}{c}\text { How many times you } \\
\text { have applied it }\end{array}$ & Content covert & & Difficulties in applying \\
\hline T01 & More than once & $\begin{array}{l}\text { Organic Functions, Food Energy, } \\
\text { Chemical Calculations }\end{array}$ & Yes & $\begin{array}{c}\checkmark \text { Lack of previously planned material. } \\
\text { Incompatible books for the } \\
\text { work with problems. }\end{array}$ \\
\hline T04 & More than once & Organic Functions & & No \\
\hline T08 & More than once & $\begin{array}{c}\text { Introduction to Chemistry (Substances } \\
\text { and Mixtures) }\end{array}$ & Yes & $\begin{array}{l}\text { Time needed to develop the } \\
\text { activities in contrast with the syllabus } \\
\text { demanded by the State Secretary of } \\
\text { Education. }\end{array}$ \\
\hline T10 & More than once & $\begin{array}{l}\text { Chemical Reactions, Chemical } \\
\text { Kinetics, Inorganic Functions. }\end{array}$ & Yes & $\begin{array}{l}\text { At first, due to the lack of } \\
\text { knowledge. }\end{array}$ \\
\hline
\end{tabular}

Source: Authors.

The participants who claimed to have used problem solving in the classroom (T01, T04, T08 and T10), even more than once, are the teachers who had taken part in continuing education activities, workshops, tutorials and disciplines in a graduation program (See Table 6.) and that somehow had had contact with this approach, even if some of these activities had not been developed exclusively on this approach.

These same teachers, except for T04, reported that they had had some difficulties in applying problem solving. This may be associated with the fact that they were not familiar with the theoretical and methodological premises that involve this approach, which would provide them with more skills to work with this approach in the classroom. By contrast, T04 was the only teacher to report not having found any difficulties in applying it. We inferred that this answer is related to the fact that T04 showed a better understanding of this approach when compared to the other teachers, which happened because the theme of T04's dissertation had been the problem-solving teaching and learning approach as informed in the interview.

\section{Analysis of Teachers' Opinions about the RPEQ Website}

In this section, we will discuss the results related to the question about teachers' opinions about the RPEQ website (What is your opinion about a website on which problems about various contents in Chemistry will be made available along with their respective didactic tools?) obtained in phase three. For the analysis of teachers' responses, we used the Content Analysis technique (Bardin, 2011). According to the author, this technique comprises three sequential phases: pre-analysis, exploration of material and treatment of results, inference and interpretation.

In the first phase, we performed a floating reading, which consisted of our "first look" (brief reading) at the material do be analyzed (questionnaire) and contributed to the determination of categories in the following phase. 
The second phase referred to the determination of the categories, which can be defined a priori or a posteriori of the analysis. In this investigation, we used a posteriori categories resulting from the analysis of teachers' responses to the questionnaire aiming to achieve the objective of this research. Subsequently, we carried out a detailed reading of the documents to categorize the responses of the teachers from the codification process, which concerns the determination of the units of records or units of meanings (keywords) and the units of context (context in which the units of registration are inserted) present in the analyzed documents. Such units make it possible to determine the categorization that aims to group data together according to common characteristics.

Finally, the third phase corresponds to the treatment of results by following some procedures such as the use of tables, figures or diagrams. In this phase, inferences and interpretation of results were also carried out.

Therefore, in the Table 6, we have listed the categories we came across in the process of analysis of teachers' description, registration units (words that are underlined), the context units referring to the context of the registration units and the code, which represent the speech of the teachers associated with the categories.

Table 6 - Categorization of teachers' opinions about the RPEQ website.

\begin{tabular}{|c|c|c|c|}
\hline Categories & $\begin{array}{l}\text { Description and } \\
\text { Registration Unit }\end{array}$ & Context Unit & Code \\
\hline $\begin{array}{l}\text { 1. Didactic } \\
\text { Resource }\end{array}$ & $\begin{array}{l}\text { RPEQ's Website as } \\
\text { backup/material/ } \\
\text { support/didactic tool to assist } \\
\text { teaching práxis. }\end{array}$ & $\begin{array}{l}\text { T04: "It will be an additional resource for the teachers who do not have } \\
\text { much time to elaborate their situational problem and didactic tools." } \\
\text { T05: "My opinion is the best one possible because it will immensely } \\
\text { facilitate teachers' lives. Especially one who likes to have practical } \\
\text { situations in the classroom, explain in a more straightforward way, not so } \\
\text { theoretical. It will be excellent because you already have everything ready } \\
\text { [...] It will be excellent! [...] And if you have any questions, just check the } \\
\text { site. [...] So you will only need to adjust your methodology and it's all ready } \\
\text { done. It will be excellent!" } \\
\text { T07: "[...] I love it! [...] I am always browsing the internet, not only in books } \\
\text { [...] If I could have all this data backup, it would be a good tool, right? For } \\
\text { me it's great! } \\
\text { T09: "I think it is a very good tool. If you manage to plan, for example, the } \\
\text { syllabus of Chemistry for high school education, it becomes a very good tool. } \\
\text { If you organize the website according to the official syllabus, it becomes very } \\
\text { easy for the teacher to find the content. So, you have: Periodic Table for the } \\
\text { first year, you click there and see which situational problem you have to } \\
\text { work with. In fact, for each theme you can have several, right? But having a } \\
\text { tool like this is essential." }\end{array}$ & $\begin{array}{l}\text { T04.1 } \\
\text { T05.1 } \\
\text { T07.1 } \\
\text { T09.1 } \\
\text { T10.1 }\end{array}$ \\
\hline $\begin{array}{c}\text { 2. Scientific } \\
\text { Dissemination } \\
\text { Support }\end{array}$ & $\begin{array}{l}\text { RPEQ's Website as a means } \\
\text { of dissemination } \\
\text { /socialization and access to } \\
\text { research developed in the } \\
\text { academic environment }\end{array}$ & $\begin{array}{l}\text { T06: "It's great! Because so you are going to... how do you say... a very } \\
\text { common word... } \underline{\text { socialize what is interesting." }} \\
\text { T08: "A great idea, because we, teachers, who are not directly in the } \\
\text { academic environment will have access to a rich material, that isn't of easy } \\
\text { access though." }\end{array}$ & $\begin{array}{l}\text { T06.2 } \\
\text { T08.2 }\end{array}$ \\
\hline
\end{tabular}




\begin{tabular}{|c|c|c|c|}
\hline $\begin{array}{l}\text { 3. Research } \\
\text { source on the } \\
\text { problem } \\
\text { solving } \\
\text { approach in } \\
\text { the teaching } \\
\text { of Chemistry }\end{array}$ & $\begin{array}{l}\text { RPEQ website for search on } \\
\text { the problem solving } \\
\text { approach in the teaching of } \\
\text { Chemistry with practical and } \\
\text { easy access. }\end{array}$ & 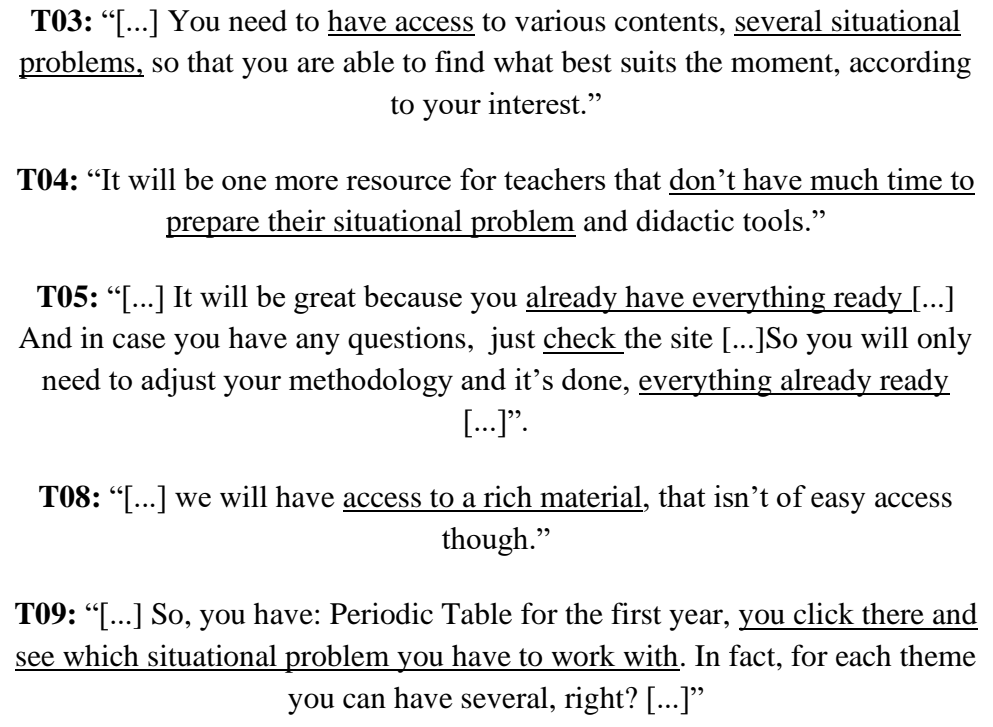 & $\begin{array}{l}\text { T03.3 } \\
\text { T04.3 } \\
\text { T05.3 } \\
\text { T09.3 } \\
\text { T08.3 }\end{array}$ \\
\hline $\begin{array}{l}\text { 4. Importance } \\
\text { of website } \\
\text { maintenance }\end{array}$ & $\begin{array}{l}\text { Teachers who highlighted the } \\
\text { importance of maintenance/ } \\
\text { updating of the RPEQ } \\
\text { website. }\end{array}$ & $\begin{array}{c}\text { T02: "I believe it absolutely valid. Absolutely valid and so.... I hope the } \\
\text { website works... and is more and more updated. Because it is useless to build } \\
\text { a website, display something there and not update it." }\end{array}$ & T02.4 \\
\hline $\begin{array}{l}\text { 5. Nothing to } \\
\text { declare }\end{array}$ & $\begin{array}{l}\text { Teachers who did not give } \\
\text { opinions about the RPEQ } \\
\text { website. }\end{array}$ & $\begin{array}{l}\text { T01: "Well, it is not easy to give an opinion about something you don't } \\
\text { know. I have already found several strategies on the internet and, despite } \\
\text { being quite familiar with them, the outcome was not satisfactory. Therefore, I } \\
\text { prefer to know it first before expressing my opinion" }\end{array}$ & T01.5 \\
\hline
\end{tabular}

Source: Authors.

As a result of the analysis of teachers' responses through the application of the Content Analysis technique, we identified five categories for teachers' opinions about the RPEQ website. In general, the opinion of the subjects regarding the proposal to build a website on the problem solving for the teaching of Chemistry was very positive and significant meaning that it can assist them in their pedagogical practice. Teachers also pointed out other additional purposes for the website.

Subjects T04, T05, T07, T09 and T10 appointed the website as a didactic resource (Category 1), which will assist them in preparing their lessons. Thus, these teachers seem to recognize the main objective of this web portal, which is to act as a digital didactic resource for teachers, so that it can contribute to their pedagogical practice in relation to a differentiated teaching proposal, facilitating the preparation of their lessons and optimizing their time. While giving their opinions, T06 and T08 raised a very important issue in our research: Scientific Dissemination (Category 2). T06 seemed to recognize our proposal for scientific dissemination of research on problem solving through the website because, in addition to act as a data bank of teaching material for teachers, this web portal aims to socialize research developed on problem solving with the general public, whether they are experts or not in the area. However, the target audience in this study was focused on basic education teachers. And due to the fact that it is an internet available resource, this first priority of ours does not exclude other potential audiences. T08 talked the problem of little scientific dissemination by the academic community even more emphatically. This teacher explained that the website will provide basic education teachers with access to knowledge discussed about in universities. From the response of T08, we were able to infer that for this participant there is a sort of gap between the academic environment and the school when the teacher explained that knowledge produced by universities is not easily accessible. At the same time, this teacher recognized the importance of research done by higher education institutions for their professional area. What is happening today is that a great amount of this research does not reach schools. 
Due to teachers' lack of time nowadays, the activity of searching for articles on the internet or in any other research medium can be configured as an obstacle to access knowledge that is being produced by universities. This reinforces our justification regarding the choice of the topic of scientific dissemination for this study, in the sense that it can contribute to fill this existing gap between researchers and basic education teachers in the field of Science Didactics.

Subsequently, T02, besides mentioning that the website was an absolutely valid idea, also made an observation regarding its maintenance (Category 4). In relation to updating the website, the initial project was to systematize the researchers developed by the RPEQ - UFRPE group, published in scientific journals. However, in a near future, our proposal is also to update the website with studies that have been developed by other university professors and researchers, who work with problem solving in the teaching of Chemistry. In addition to this, as the members of the RPEQ group develop new research and new problems we will be carrying out this process of updating the RPEQ website.

For T03, T04, T05, T08 and T09, the RPEQ website provides access to the problem solving approach and problematic situations about several contents in Chemistry (Category 3) acting as a source of research in this area. Thus, the systematization of these studies allows the teacher to choose the most appropriate problem in view of the content being addressed in the classroom.

Regarding category 5, mentioned only by T01, it's important to recall that we chose to take a printed version of the situational problems instead of the website electronic page for the interview. Therefore, this teacher preferred not to give an opinion, although, even if in a printed version, they had had an explanation of the proposal of the web portal presenting its content.

\section{Final Considerations}

Concerning knowledge and use of the problem-solving approach in the classroom, some teachers claimed to know this didactic approach and that they had used this approach in the classroom. And they also reported some difficulties they had faced while using it.

Overall, the opinions presented by the teachers regarding the RPEQ website were very positive and significant. Most teachers stated that the RPEQ website will act as a didactic support, helping them in the preparation of their lessons, providing access to various problematic situations about various contents in Chemistry. One teacher also stated that the website was an absolutely valid idea, but stressed the need of maintenance of the electronic address. And there were teachers who mentioned the issue of scientific dissemination, meaning that there are few activities towards this direction carried out by academic communities. For these teachers, the website will allow basic education teachers to have access to knowledge that is being discussed about in universities.

By promoting scientific dissemination of research on problem solving in the teaching of Chemistry through the RPEQ website, we were able to provide teachers' contact with a different didactic approach when compared to the one they are used to performing in the classroom based, generally, on a traditional conception of teaching.

With the creation of this website, we hope to contribute to minimize the difficulties pointed out by teachers with problem solving, especially in relation to the lack of materials published on this approach in the teaching of Chemistry, and the planning time required for a lesson plan based on this approach that includes the elaboration of a problem, which is not an easy task. We also hope that we have inspired and encouraged teachers to apply and continue applying problem solving activities in the classroom and that at the same time they may disseminate the RPEQ website to other colleagues.

Given to this study, we were able to provide the interaction between research professors at UFRPE and basic education teachers as Schnetzler (2002) suggests. In addition to this, the activity of scientific dissemination done in this research also contributed to minimize the problem raised by Torresi et al.. (2012) regarding the little scientific dissemination carried out. 
And still put into practice the proposals of the current National Curriculum Guidelines of 2015, with regard to the promotion of scientific dissemination. According to Masih (2012): “though work on science popularization is being carried out world-wide, it is still found to be less than the total recorded research found in scholarly journals. The gap between scientific discovery and popularizing that discovery should be reduced". In this sense, this study seeks to contribute.

Finally, we hope that in fact the RPEQ website may assist chemistry teachers in their pedagogical practice in relation to the problem solving approach, acting as a digital didactic resource, facilitating the preparation of their lessons and optimizing their time. And, in addition to this, contribute to draw basic education active teachers closer to research on the different teaching strategies developed by higher education institutions. Also, by promoting scientific dissemination of research on problem solving in the teaching of Chemistry through the RPEQ website in the initial formation to provide teachers' contact with a diferente didactic approach when compared to the one they are used to performing in the classroom based, generally, on a traditional conception of teaching.

\section{Acknowledgments}

Special thanks to CAPES (Coordenação de Aperfeiçoamento de Pessoal de Nível Superior) and FACEPE (Fundação de Amparo a Ciência e Tecnologia do Estado de Pernambuco) for financial support for this research.

\section{References}

Bardin L. (2011). Análise de conteúdo. Edições 70.

Bak H. (2001). Education and public attitudes toward science: implications of de "Deficit model" of education and support for science and technology. Social Science Quarterly, 82(4), 779-795.

Baran M. \& Sozbilir M. (2018). An Application of Contextand Problem-Based Learning (C-PBL) into Teaching Thermodynamics. Res. Sci. Educ., 48(4), $663-689$.

Barata G. Caldas, G. \& Gascoigne, T. (2018). Brazilian science communication research: national and international contributions. Annals of the Brazilian Academy of Sciences, 90(2 Suppl. 1): 2523-2542.

Barrows H. S. (1986). A taxonomy of problem-based learning methods. Medical Education, 20(6), 481-486.

Brasil (2015). Diretrizes curriculares nacionais para a formação inicial e continuada dos profissionais do magistério da educação básica. Ministério da Educação, Brasília.

Bueno W. C. (2007). Jornalismo ambiental: explorando além do conceito. Desenvolvimento e Meio Ambiente, 15, p. 33-44.

Bueno W. C. (2010). Comunicação científica e divulgação científica: aproximações e rupturas conceituais. Informação \& Informação, 15 (1), 1-12.

Castelo Branco A. K. A. (2015). Difusão Científica da universidade à escola. Paco Editorial.

Castro C., Andrade A. \& Lagarto J. (2015). Utilização pedagógica de repositórios: um estudo exploratório com professores de física e química. In: P. Membiela, N. Casado, M. I. Cebreiros, Presente e Futuro do Ensino das Ciências, 85-89 Educación Editora.

Cowden C. D. \& Santiago, M. F. (2016). Interdisciplinary Explorations: Promoting Critical Thinking via Problem-Based Learning in an Advanced Biochemistry Class. Journal of Chemical Education, 93(3), 464-469.

Fernandes L. S. \& Campos A. (2014). Elaboração e aplicação de uma intervenção didática utilizando situação-problema no ensino de ligação química. Experiências em Ensino de Ciências, 9(1), 37- 49.

Ferreira I. M., Fernandes L. S. \& Campos A. F. (2016). Abordagem de ligação metálica numa perspectiva de ensino por situação-problema. Revista Brasileira de Ensino de Ciência e Tecnologia, 9(2), 93-107.

Fenshaw P. (1999). School science and public understanding of science. International Journal of Science and Education, $21(7), 755-763$.

Freitas, A. P. \& Campos, A. F. (2019). Impressões de professores de Química acerca da abordagem de resolução de problemas a partir da Divulgação Científica. Revista de Educação, Ciências e Matemática, 9(1), 116-128.

Goi, M. E. J.; Santos, F. M. T. Laboratório Experimental e Resolução de Problemas: construção do conhecimento químico. Research, Society and Development, v. 9, p. 90922076, 2020.

Groth P. \& Gurney T. (2010). Studying Scientific Discourse on the Web Using Bibliometrics: A Chemistry Blogging Case Study. Web Science Conference, Raleigh, NC, USA. 
Gunter T. \& Alpat S. K. (2017). The effects of problem-based learning (PBL) on the academic achievement of students studying 'Electrochemistry. Chem. Educ. Res. Pract., 18(1), 78-98.

Günter T., Akkuzu N. \& Alpat S. (2017). Understanding 'green chemistry' and 'sustainability': an example of problem-based learning (PBL). Res. Sci. Technol. Educ., 35(4), 500-520.

Kenski V. M. (2015). Educação e tecnologias, Papirus editora.

Lacerda C. C., Campos A. F. \& Marcelino JR. C. A. C. (2012). Abordagem dos conceitos mistura, substância simples, substância composta e elemento químico numa perspectiva de ensino por situação-problema. Química Nova na Escola, 34(2), 75-82.

Laughsch R. C. (2000). Scientific literacy: a conceptual overview. Science Education, 84(1), 71- 94.

Leite B. S. (2015). Tecnologias no ensino de química: teoria e prática na formação docente. Appris.

Lopes R. M., Silva Filho M. V., Marsden M. \& Alves N. G. (2011). Aprendizagem baseada em problemas: uma experiência no ensino de química toxicológica. Química Nova, 34(7), 1275-1280.

Masih W. (2012). Efforts towards popularisation and public understanding of science: a literature review of 30 publications. International Journal of Scientific \& Engineering Research, 3(9), 1-7.

Nascimento, T. G. (2008). Definições de Divulgação Científica por jornalistas, cientistas e educadores em ciências. Ciência em tela, 1(2), 1-8.

Merino J. M. \& Herrero F. (2007). Resolución de problemas experimentales de Química: una alternativa a las prácticas tradicionales. Enseñanza de las Ciencias, 6(3), 630-648.

Millar R. (2003). Towards a science curriculum for public understanding. Ens. Pesqui. Educ. Ciênc., 5(2), 7-18.

Nagarajan S \& Overton T. (2019). Promoting Systems Thinking Using Project- and Problem-Based Learning. Journal of Chemical Education, 96(12), 29012909.

Nascimento A. C. A. A. (2009). Aprendizagem por meio de repositórios digitais e virtuais. In: F. M. Litto, M. Formiga. Educação à distância: estado da arte, 352-357, Pearson.

Nascimento T. G. \& Rezende Junior M. F. (2010). A produção sobre divulgação científica na área de Educação em Ciências: referenciais teóricos e principais temáticas. Revista Investigações em Ensino de Ciências, 15 (1), 97-120.

Overton T. L. \& Randles, C. A. (2015). Beyond problem-based learning: using dynamic PBL in chemistry. Chem. Educ. Res. Pract., 16(2), $251-259$. Oliveira M. M. (2016). Como fazer pesquisa qualitativa. Vozes.

Pasquali A. (1979). Compreender la comunicación. Monte Ávila Editora.

Santos A. R., Firme C. L. \& Barros J. C. (2008). A Internet como fonte de informação bibliográfica em Química. Química Nova, 31(2), 445-451.

Schnetzler R. P. (2002). A Pesquisa em ensino de química no brasil: conquistas e perspectivas. Química Nova, 25(1), 14-24.

Silva, E. R. A.; Braibante, M. E. F. Análise das publicações sobre metodologia de resolução de problemas e temáticas na formação inicial de professores de química. Research, Society and Development, v. 9, p. 42911589, 2020.

Shultz G. V. \& Zemke, J. M. (2019). "I Wanna Just Google It and Find the Answer": Student Information Searching in a Problem-Based Inorganic Chemistry Laboratory Experiment. Journal of Chemical Education, 96(4), 618-628.

Tawfik A. A. (2015). Essential Readings in Problem-Based Learning: Exploring and Extending the Legacy of Howard S. Barrows. Purdue University Press.

Torresi S. I. C., Pardini V. L. and Ferreira V. F. (2012). Sociedade, divulgação científica e jornalismo científico. Química Nova, 35(3), $447-447$.

Turner S. (2008). School science and its controversies; or, whatever happened to scientific literacy? Public Understanding of Science, 17(1), 55-72.

Turney J. (2004). Accounting for explanation in popular science texts - an analysis of popularized accounts of superstring theory. Public Understanding of Science, 13, 331-346.

Verissimo V. B. \& Campos A. F. (2011). Abordagem das propriedades coligativas das soluções numa perspectiva de ensino por situação-problema. Revista Brasileira de Ensino Ciência e Tecnologia, 4(3), 101-118. 